\title{
MUSEUMS IN ICELAND
}

\author{
Helgi M. Sigundsson
}

In Iceland there are close to 70 museum collections which is a considerable number bearing in mind that the country has a population of only 260000. In almost every district and town, not to mention the capital, people have cooperated in collecting objects that reflect the way of life and culture of the nation's past. The main task of most museums is to collect and preserve objects or pieces of art. Apart from exhibiting these objects, some museums organize special exhibitions, lectures and concerts. Most of the larger museums offer professional advice in their fields, e.g. on buildings, objects and preservation.

About four out of every five museums (i.e. 48) are ethnographic (folk museums); there are 13 art museums and 10 natural history museums. A few museums are combinations of these three categories. The distribution of these museums is noteworthy: the ethnographic and natural history museums are distributed evenly around the country, while most of the art museums are situated in Reykjavik. In this article the focus is on the cultural history museums, but articles on the art and natural history museums will hopefully follow.

\section{THE NATIONAL MUSEUM OF ICELAND - ITS FOUNDATION AND DEVELOPMENT}

The history of the National Museum goes hand in hand with the various stages in the nation's drive towards national independence. It all began around 1830 and was a part of the rising interest in the history and culture of the nation. The idea of founding a museum was first introduced in 1862 in an article by Sigurdur Gudmundsson, known as the "painter".
Among other things, Gudmundsson had designed a new national costume for women which would later become quite popular. Regarding historical objects, he probably regretted seeing so many items leave the country over the years. In response to Gudmundsson's article an open letter was published from one Helgi Sigurdsson which emphasized the value of old objects and the necessity of establishing a museum of antiquities. As an encouragement Sigurdsson donated a number of objects to the nation. 
50 What is remarkable is just how quickly the ideas of these two men were realized. Early in 1863 the National Museum of Iceland was established with Gudmundson as its curator, a position he held until his death in 1874. Because of his endeavours, Gudmundsson has often been termed the founding father of the National Museum. His successor was to be Jón Árnason, a prominent figure in the field of Icelandic folklore.

Initially the National Museum was supposed to collect artefacts and works of art. One of its first curators, Sigurdur Vigfússon, also carried out the first archaeological excavation in the country. In this first phase the National Museum was relatively small compared to what it became later. It had to change premises no less than three times up to 1908 .

A major milestone in the struggle for national independence was reached in 1904 when Iceland gained home rule. As a result there was an extensive revision of legislation in the areas of culture and education. This included initial legislation governing the preservation of antiquities in Iceland passed in 1907. A year later the National Museum moved to its first longterm premises, i.e. the Museum Building at Hverfisgata in Reykjavík, which it shared with three other museums for the next 42 years. As previously, one person was responsible for the museum and this remained the case until 1947.

Final victory in Iceland's struggle for full independence came in 1944 . To celebrate the historic occasion a large and impressive building was planned to house the National Museum. It was built in the following years and the National Museum has been there ever since. The erection of the museum building was the greatest achievement in the museum's history since its establishment.

\section{THE NATIONAL MUSEUM OF ICELAND - ITS PRESENT STATE}

By law, the National Museum's brief is to preserve Icelandic national treasures in a broad sense, whether these be objects in the museum itself or antiquities, and to protect buildings of historical interest. The museum is the property of the Icelandic state.

The staff of the National Museum has increased over the years. Today about 20 specialists are employed, along with other full-time employees and guards in the exhibition halls. Over the summer the number of staff increases, both for supervising historical buildings in rural areas and for carrying out archaeological excavations.

The National Museum is first and foremost a museum of Icelandic objects. Close to 20000 items are catalogued in the main record, however there are also special collections of which the largest, Ásbúdarsafn, has 13000 items. The National Museum constantly receives a variety objects, both as gifts from individuals and companies, and through the initiative of the museum's specialists. The National Museum runs a conservation workshop where museum objects receive the care and treatment they require. The municipal museums and churches often seek the museum's advice and support in preserving old and valued objects.

In the exhibition halls of the National Museum there are objects spanning every century of Icelandic history, i.e. woodcar- 


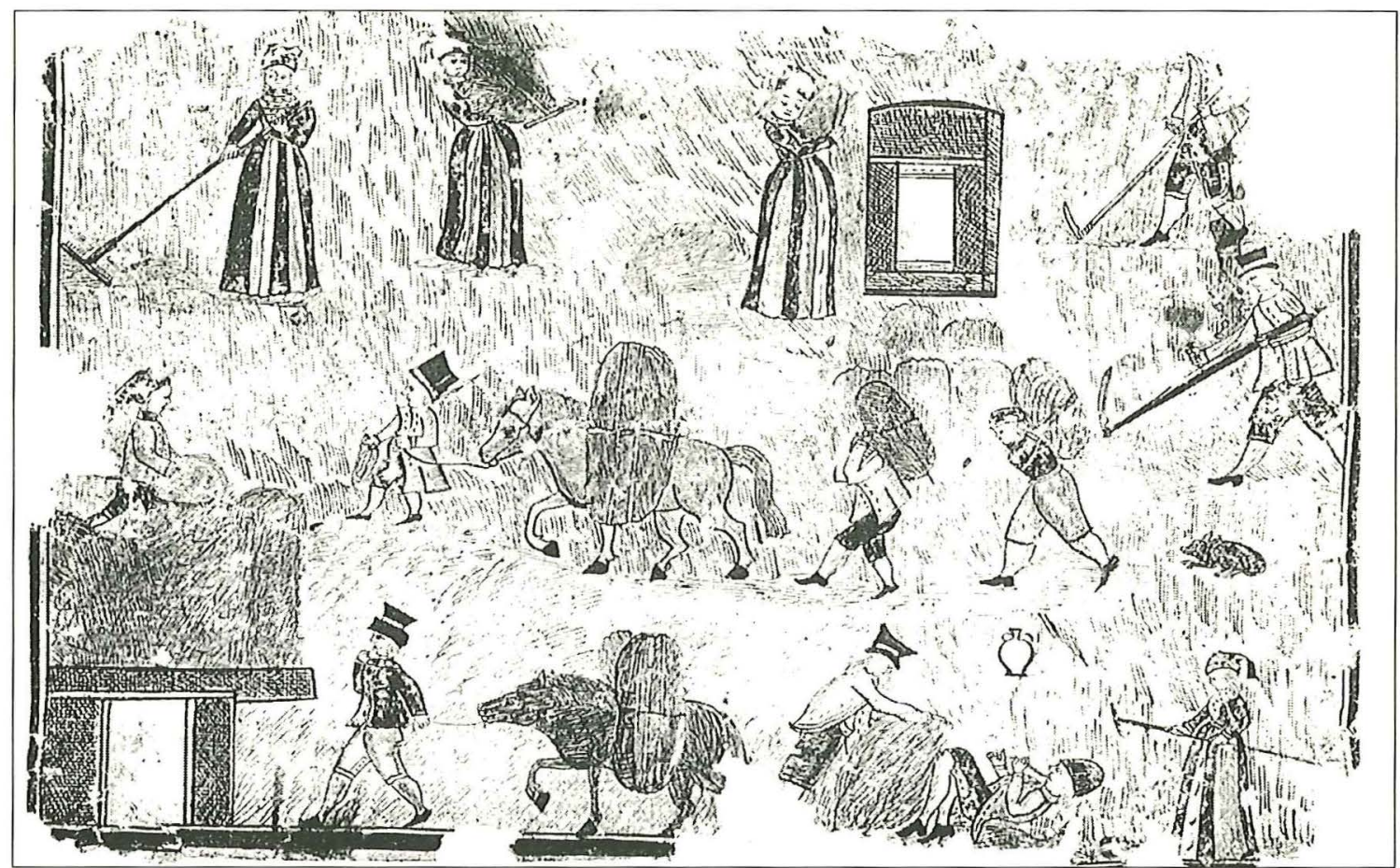

Haymaking in Iceland. A drawing from the 18th century. The National Museum of Iceland.

ving, metalwork, church ornaments, textiles, farm tools and fishing tackle, to mention but a few. Special exhibitions are also set up on a regular basis for limited periods.

Extensive work in the fields of catoguing and research is done at the National Museum, e.g. on museum objects of all kinds. The regular collection of data on ethnological matters is another vital aspect of the museum's work. The information on people's daily life, work, clothing, eating habits, etc. now covers more than 100000 pages. Since 1908 considerable effort has also been put into collecting photographs and other pictorial material.

The National Museum is responsible for antiquities in Iceland. The museum is obliged to record antiquities and care for national treasures, and to organize and handle archaeological research. Furthermore, the National Museum is responsible for the care and protection of Iceland's architectural heritage. A few turf-houses still survive, as well as timber houses round about the country, and some stonebuilt houses from the 18th century.

The research findings of the National Museum and articles written by museum staff are published in the yearbook Arbók Hins islenska fornleifafélags, which has been published since 1881. In addition the museum publishes books and booklets on diverse subjects. The museum also employs a teacher to act as a guide for children and other visiting groups.

\section{LOCAL MUSEUMS}

In 1947 legislation regarding antiquities was extended to include old buildings and local museums. At that time no such museums had actually been opened, but the collecting of items had begun in several districts round about the country. In the main this was due to an awareness that the old peasant culture and with it traditional working methods was quickly vanis- 
HELGI M. SIGURDSSON

52 hing because of the rapid changes in the structure of society. It was therefore deemed neccessary to preserve certain objects before they were lost forever.

Owned by the local municipalities, local museums are meant to be representative of their districts. By law they are expected to emphasize objects which were characteristic of the way of life in the locality. Since it was foreseen that these museums would have few financial resources, they were permitted to use preserved buildings to house exhibits. The old turf houses particularly came to mind, since they were fitting places in which to exhibit tools and other objects from the peasant communities of the 19th century. In this way historical buildings were given a practical purpose and the finance necessary for their maintenance was better secured. For museums located on the coast, the emphasis was to be on fishing from open boats, a seafaring method practised for many centuries.

After 1950 the local museums began opening one after the other. The first one, Glaumber Folk Museum in Skagafjördur, was in an old turf farmhouse. The items on exhibit there are considered to ideally reflect the way of life of the old farming community in the district. It would also seem that having a turf house as a museum influenced the type of articles collected. A large number of visitors come to Glaumbær every summer, which speaks for itself regarding public interest. On the negative side turf houses are an unsuitable environment for the preservation of museum items, both because of humidity and the greater risk of theft than in orthodox buildings.

Other local museums were either situa- ted in old buildings or in parts of public buildings, sometimes the least desirable sections, e.g. cellars or attics. The reason for this was that district authorities were usually unprepared to finance new buildings. However in later years the housing situation has improved considerably.

One reputable museum in a rural locality is the Skógur Folk Museum in the southern part of the country. A third one, and the largest outside Reykjavík, is Akureyri Museum.

Now that local museums have passed through their first period of developement a debate has arisen as to their function and methods. The original aim had been to preserve glimpses of a bygone peasant community. For the most part that has been successfully achieved, but now there are those who say that museums should broaden their scope and offer variety as educational and cultural institutions. Museums, they argue, should not only focus on the old peasant society, but also on more recent periods in our history. Another subject for discussion is the division of emphasis between museums. Some maintain that museums are too much alike, so tourists do not find it interesting enough to visit more than one of them.

\section{ARBAJARSAFN - REYKJAVIKK MUSEUM - AND OTHER MUSEUMS IN THE CAPITAL}

About half the Icelandic population lives in the Reykjavík area and the capital's local museum is Arbajarsafn, Reykjavik Museum. It is different from the museums in rural areas in that it mainly collects features from a town and not a rural culture.

The collecting of historical objects star- 
ted in Reykjavík in the 1940 's. At that time more and more people were realizing that "the old Reykjavík» was fast disappearing and would soon be lost forever. In 1954 the Reykjavík Local Museum was founded. It was given premises and the city's archivist was appointed its curator. In 1957 an open-air museum was established at the farm Árbær, which was then on the outskirts of Reykjavík. Árbæjarsafn's first task was to re-build the old farmhouses which had been made of turf and stone following the 19th century tradition. After that the museum began moving old houses from the city centre to the area. Today these buildings number more than twenty.

Árbæjarsafn, Reykjavík Museum, was first intended as an open-air section of the Reykjavík Local Museum. However in 1968 the local museum was also transferred to the site and since then Árbxjarsafn has played a greater role, both in collecting items and carrying out research. Yet, despite the developments, the open-air museum section is still where the major focus is. The reason for this is perhaps the museum's close proximity to the National Museum, which is also situated in Reykjavík and and has always served as the city's local museum along with its other functions.

Árbæjarsafn, Reykjavík Museum, has six departments. The museum's holdings department oversees objects in the museum's collection. Catalogued objects number about 16000 and altogether there are in the region of 25000 items. The picture department collects and preserves photographs, maps, paintings, glass-plate negtives and other pictorial material. The architecture department conducts research into the architectural history of Reykjavík and gives advice on the rebuilding of old houses. The archaeological department takes care of more than one hundred sites within the city where archaeological finds have been registered and also supervises archaeological excavations in Reykjavík. Lastly, the education and exhibits depart-

Old-time transport at the Arbajarsafn, Reykjavik Museum: Model-T Ford of 1917. Some of the museum buildings are in the background. 1990/RAX.

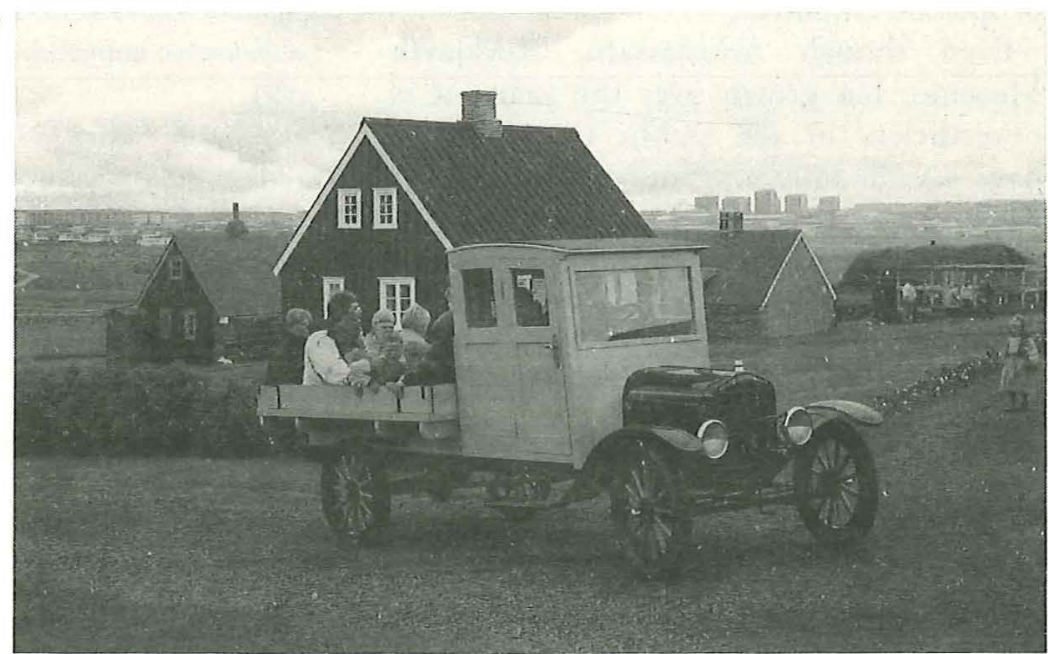


54 ment sets up exhibitions along with organizing events and workshops. It also receives school groups and other parties visiting the museum. The museum has become increasingly popular over the last few years, mainly due to the special events and workshops that are held every Sunday during the summer. Since Árbæjarsafn, Reykjavík Museum, is an open-air museum it has the means to stage events relating to handicrafts, cottage industry, agriculture, traditional sports, etc. The museum houses a carpenters' workshop that maintains the museum buildings. Árbæjarsafn, Reykjavík Museum, publishes a wide variety of printed material, ranging from postcards to books. However the most extensive publications are research reports.

The activities at Árbæjarsafn have become increasingly diversified and today its budget is almost equivalent to that of the National Museum. Once there was only a single employee at Árbæjarsafn, now there are 20. During the summer, when the whole museum is open, about 40 more people are employed.

Even though Árbæjarsafn, Reykjavík Museum, has grown over the years, it is nevertheless in the public's interest to have several museums and institutions in Reykjavík working in the same areas, e.g. the collecting of items and pictorial material. The National Museum plays an active part in the collecting of items. In addition there has been a general awakening of interest in the city which has resulted in the setting up of various special interest museums or collections in the last decade or so. The largest of these are the Reykjavik Electricity Board Museum, the Maritime Museum of Josafat Hinriksson and the Post and Telecommunications Museum. The National Museum also plays an active role in the field of photography, as does the Reykjavik Museum of Photography. It is important for these museums to discuss their fields of interest and their functions formally, in particular the National Museum and Árbæjarsafn, Reykjavík Museum, but also these two major museums and the various special interest museums.

\section{BIBLIOGRAPHY}

A key book for foreigners on Icelandic museums is "Söfn á Íslandi", edited by Ragnhildur Vigfúsdóttir, Rv. 1993. It is in both Icelandic and English and deals with each museum individually. The publisher is the ICOM-division of Iceland. Other books used in this overview are the following:

Helgi M. Sigurdsson: Arbøjarsafn. Leidsögubók. Reykjavík 1994.

Kristján Eldjárn: Hundrad ár $i$ Tjódminjasafni. Reykjavík (undated).

Ragnhildur Vigfúsdóttir: Könnun á islenskum minjasöfnum (an unpublished report). Reykjavík 1991.

Tjódminjasafn Íslands 125 ára. Reykjavík (undated). Tór Magnússon: Byggdasöfnin og hlutverk fleirra. Söguspegill, p. 22-29. Reykjavík 1992.

Helgi M. Sigurdsson is a BA in history and a cand. mag. in literature from the University of Iceland. Since 1989 a curator at Árbajarsafn, Reykjavik Museum, and in charge of the collection department from its establishment in 1991. Adr: Arbajarsafn, Reykjavik Museum, P.O. Box 10020, IS-130 Reykjavík

Fax $+354-5673620$ 